\begin{abstract}
Iranica
Abstracta Iranica Revue bibliographique pour le domaine irano-aryen

Volume 34-35-36 | 2017

Comptes rendus des publications de 2011-2013
\end{abstract}

\title{
Şevket Dönmez. A Crater Fragment with partridges from Oluz Höyük, Central Black Sea Region, Turkey
}

\section{Astrid Nunn}

\section{(e) OpenEdition}

\section{Journals}

Édition électronique

URL : http://journals.openedition.org/abstractairanica/41445

DOI : 10.4000/abstractairanica.41445

ISSN : 1961-960X

Éditeur :

CNRS (UMR 7528 Mondes iraniens et indiens), Éditions de l'IFRI

Référence électronique

Astrid Nunn, « Şevket Dönmez. A Crater Fragment with partridges from Oluz Höyük, Central Black Sea Region, Turkey ", Abstracta Iranica [En ligne], Volume 34-35-36 | 2017, document 13, mis en ligne le 15 juillet 2016, consulté le 04 octobre 2020. URL : http://journals.openedition.org/abstractairanica/41445 ; DOI : https://doi.org/10.4000/abstractairanica.41445

Ce document a été généré automatiquement le 4 octobre 2020.

Tous droits réservés 


\title{
Şevket Dönmez. A Crater Fragment with partridges from Oluz Höyük, Central Black Sea Region, Turkey
}

\author{
Astrid Nunn
}

\section{RÉFÉRENCE}

Şevket Dönmez. « A Crater Fragment with partridges from Oluz Höyük, Central Black Sea Region, Turkey ». Ancient West \& East, vol. 10, 2011, p. 339-347.

1 Cet article ne traite que d'un tesson de céramique trouvé à Oluz Höyük, situé au sudouest d'Amasya en Turquie. Ce tesson de $13 \times 15 \mathrm{~cm}$, provenant d'une couche du $\mathrm{V}^{\mathrm{e}} \mathrm{s}$. av. J.-C., montre deux perdrix peintes. Ce sujet est rare et remonte en Anatolie Centrale au $\mathrm{VI}^{\mathrm{e}}$ s., où il apparait sur de la céramique et sur des tuiles décoratives. Il semble avoir atteint l'Anatolie par l'intermédiaire des Phrygiens et des Mèdes.

\section{AUTEURS}

ASTRID NUNN

Université de Munich 